Assam Adventure

By F. Kingdon Ward. Pp. $304+16$ plates. (London : Jonathan Cape, Ltd., 1941.) 12s. 6d. net.

THIS is the kind of book that makes any flowerlover's mouth water. Kingdon Ward had, of course, to make the chance for himself. But what a chance it was! Wandering about in a flower paradise with nothing else to do but collect the most glorious plants. Thirty-nine rhododendrons-that alone should be enough to satisfy most plant lovers; but in addition such treasures as the Tibetan blue poppy, known all over the world as Meconopsis baileyi but now more accurately described as the Meconopsis betonicifolia baileyi; then ten different species of primulas and seven gentians. All these Kingdon Ward has through three journeys into south-western Tibet been able to introduce into cultivation in the West. It is a great contribution to the happiness of mankind and some little set-off to the present horrors of war.

We could have wished that Kingdon Ward had that other plant-collector, Reginald Farrer's, gift of description. But Farrer was a literary genius at describing flowers such as comes only once in two or three generations; and if he could not find the exact word to describe the colour or form of a flower he would deliberately coin a word for it. Kingdon Ward lacks that gift. But he has to some extent made up for it by the beautiful photographs with which his book is illustrated and which give us a fine impression of the kind of country in which the flowers are found. This is another important part of Kingdon Ward's work : he describes in detail the physical conditions of temperature or moisture, of shade or sunshine under which the many plants he has introduced to cultivators are found in their own native habitat.

F. Y.

Historic Thorn Trees in the British Isles

By Dr. Vaughan Cornish. Pp. $94+9$ plates. (London : Country Life, Ltd., n.d.) $8 s .6 d$.

D. VAUGHAN CORNISH in his interesting study of historic thorn trees shows that their distribution in England coincides strikingly with the areas invaded in the south by the Belgic tribes from Gaul, and in northern England, by the Parisii, an adjoining tribe. From these tribes probably originated the cult of the thorn as a sacred tree--a cult still persisting in some remote districts in England, and common in Ireland, where the fairy trees are protected with superstitious reverence. The legend of the Glastonbury thorn gathered Christian associations around the thorn.

These cherished trees planted in later times as marks for assemblies of 'hundreds' or parishes, or as forest boundaries, and in some instances-as in that of the author's own inheritance, the Salcombe Regis Thorn-maintained by replanting to the present day, trace back in their story the history of their locality. Rectors of country parishes and anyone with an interest in the past and present of their district will find Dr. Vaughan Cornish's account of the thorn trees fascinating
The English May tree speaks of our past. May Day celebrations gather round it to-day. The fresh emphasis the War has given to the value of English trees should make this history of one of the most characteristic, timely.

The Nature of the Chemical Bond and the Structure of Molecules and Crystals

An Introduction to Modern Structural Chemistry. By Prof. Linus Pauling. (The George Fisher Baker Non-resident Lectureship in Chemistry at Cornell University.) Second edition. Pp. xvi+450. (Ithaca, N.Y. : Cornell University Press; London: Oxford University Press, 1940.) 28s. net.

7 HIS book is lineal successor in a series of famous books dealing with structural chemistry from a physical point of view, the first of the line being G. N. Lewis's "Valence and the Structure of Atoms and Molecules". The first edition of Prof. Pauling's work was published two years ago. Its well-merited popularity led to the exhaustion of the first edition, and a second has now been prepared. This preserves practically the whole of the text of the original edition, but is improved and brought up to date by the inclusion of a further 20 pages, devoted mainly to the discussion of structures which have been studied by quantitative methods since the earlier edition was prepared for press. To a subsidiary extent the new matter consists of various expansions of the theoretical argument of the original work. The molecules of which the structures are discussed for the first time include the $\mathrm{Mo}(\mathrm{CN})_{8}{ }^{\prime \prime \prime \prime}$ ion, which has the remarkable form of a triangle-faced dodecahedron, and cis-azobenzene; the new crystal structures include silicon disulphide and molybdenite.

\section{Science in Peace and War}

By Prof. J. B. S. Haldane. Pp. 229. (London : The Scientific Book Club, 1941.) 2s. 6d.

THE suspension of the Daily Worker has deprived 1 the public of Prof. J. B. S. Haldane's weekly articles on scientific developments. The Scientific Book Club has, however, come forward and issued a new edition of his second set of collected articles. His new readers will find much entertaining material, for no one equals Prof. Haldane at casual human. comment on the facts of science.

In connexion with the Thetis disaster, Prof. Haldane gives some very interesting detajls about his father's researches, which commenced with analyses of the air in the slums of Dundee in 1885 and 1886. Sometimes as many as eight persons occupied one bed in a single room, while in other cases there was no bed at all. His investigations convinced him that the high death-rate in overcrowded houses was not due to chemical causes, but to bacteria. He experimented on himself, and on his son. From the age of ten, Prof. Haldane used to accompany his father on research expeditions in mines. He tells us that his father always said that the most interesting physiological problems are those which arise in ordinary life.

J. G. Crowther. 